\title{
DISCOURSE ON PROFESSIONALISATION IN THE PRACTICE OF PUBLIC HEALTH PROFESSIONALS PROVIDING SERVICES TO PERSONS WITH DISABILITIES
}

\author{
Birutė Anužienė \\ Klaipeda University, Lithuania \\ Sigutė Norkienè \\ Klaipeda University, Lithuania \\ Marina Voropajeva \\ Klaipeda University, Lithuania
}

\begin{abstract}
This article is aimed to discuss findings of the study on professionalisation in the practice of public health professionals who provide services to persons of all ages with disabilities. The following problematic questions are raised: how does a public health specialist become a professional competent in providing their services to all citizens, regardless of age or health status? What are the possible professionalisation ways and opportunities for public health professionals who provide services to persons of different age with disabilities? The article presents a theoretical discourse of the professionalisation process, as well as results of the qualitative research so as to provide insight into possible ways (opportunities) for professionalisation of public health professionals in providing services to persons of different ages with disabilities. The study is novel in that it discloses dimensions (professionalism and professionism) of a public health specialist's professionalisation process in working with persons of different ages with disabilities. As findings of the study show, the dimensions are theoretically inseparable from each other, though, with quite different ways of professionalisation in practice. The study has established that the ways of professionalisation (1.Work-based learning; 2.Reflection and activities; 3.Reflection on activities (formalisation of unexpressed competencies); 4.Reflection for activities; 5.Organisational culture and activities; 6.Integration/assimilation of knowledge) enable a person to develop existing competencies, to construct a professional identity through the integration of both aspects of relevance of professionalisation ways: practical activities and reflection.
\end{abstract}

Keywords: competencies, disability, professionalisation, public health professionals.

\section{Introduction}

Public health care is a totality of organisational, legal, economic, technical, social, and medical measures that help to prevent diseases and injuries, to preserve and enhance a society's health, and is a part of the Lithuanian national 
health system. The health care system in many countries (Lithuania is no exception) is complex, but rather difficult to manage in social terms (Glouberman \& Mintzberg, 2002, p. 14), although its separate elements are quite simple. In a social context of an organisation, matters become more complicated when different elements of the said system, including the professionalisation of professionals, get into a whole. So, a better understanding or an insight into such a complex system needs an analysis from the perspective of phenomenology of various sciences (medicine, sociology, management, etc.). This is particularly the case for the provision of public health services or the professionalisation of respective players. Here, a provider or a recipient of the service is seen as an embodied social player, who is subjectively facing a disability in his or her daily life and is influenced by social relations, yet, at the same time he or she is creating, maintaining, and interpreting social reality through daily practices.

The review of study programmes of Lithuanian universities for public health professionals allows arguing that the graduates know and recognise principles and policies of modern public health, are able to analyse natural, work environment, demographic, life quality, behavioural and lifestyle characteristics, to assess health of the society and its separate groups, to develop and implement health promotion programmes, and to evaluate their effectiveness. The qualification obtained confers the right to work in municipal public health offices, public health centres, health care departments of county or municipal administrations, departments of the health insurance fund, personal health care institutions, educational establishments, etc. However, none of the study programmes indicates that the graduates will be able to provide their services to people of all ages with disabilities. Though, in reality they “...must arrange and implement public health promotion and education in the community, provide public health promotion and education services to various population groups" (Order of the Minister of Health of the Republic of Lithuania ..., 2018), including people of different ages with disabilities. For example, it should be noted that when providing public health promotion services, which include health education for citizens of all ages and medical conditions, dissemination of information on healthy lifestyles, promotion and formation of healthy lifestyles and reduction of behavioural risks factors in public health, a specialist needs not only biomedical, but also pedagogical, andragogical, communication knowledge and skills. However, study programmes do not emphasise such knowledge or skills that would presume awareness of the application of various educational approaches (pedagogy or andragogy). The relevance of the research is also determined by previous studies on the process of professionalisation of public health professionals in providing services to persons with disabilities of different age groups. 
Since the study programmes do not emphasise the practice of public health professionals in providing services to people of all ages with disabilities, this situation presupposes the following problematic research questions: How does a public health specialist become a professional competent in providing their services to all citizens, regardless of age or health status? What are the possible professionalisation ways and opportunities for public health professionals who provide services to persons of different age with disabilities?

The aim of this study is to show the discourse on professionalisation in the practice of public health professionals, providing services to people of all ages with disabilities.

The research is based on the following theoretical and methodological provisions: a) the concept of professionalisation (Wittorski, 2007; 2008; 2009) and its dimensions (professionalism and professionism) (Bourdoncle, 2000); b) post-positivist philosophical ideas that cognition of reality has a certain structure of probability, while preference is given to an analysis of social reality, which is observed objectively and impartially by the researcher (Bourdieu \& Wacquant, 1992). A key feature of the concept of post-positivism is a role of a scientific cognition instrument, which interconnects the subjectivity and objectivity of cognition (Baranauskienè, 2020). The data obtained by the qualitative research instrument can, therefore, be compared, summarised, and interpreted as an objective reflection of reality.

The study is novel in that it discloses the dimensions (professionalism and professionism) of a public health specialist's professionalisation process in working with persons of different ages with disabilities. As findings of the study show, the dimensions are theoretically inseparable from each other, though, with quite different ways of professionalisation in practice.

\section{Theoretical Assumptions of the Research}

Theoretically, professionalisation means the acquisition and development of specific knowledge and skills necessary to master situations in professional activities (the dimension of professionalism) and expresses the idea of construction and formation of social status, professional identity (the dimension of professionism) (Bourdoncle, 2000, p. 122). In practice, professionalisation and its different dimensions, i.e., professionalism and professionism, become a particularly relevant topic, when integrating, establishing oneself in an occupational activity, developing one's own professional activity project, or ensuring long-term social sustainability. These two dimensions of professionalisation actually not only manifest themselves differently, but complement and enrich each other, as well. 
The process of professionalisation is analysed from a broad variety of perspectives; in terms of sociology, it is an object of in-depth study as a construction of new professions or occupations (Bourdoncle, 2000; Bresnen, 2013;); from educational (Graber \& Haberey-Knuessi, 2017; Guillaumin \& Wittorski, 2014; Levesque \& Gervais, 2000; Poulin, 2016; Roquet, 2012; 2013; Roquet \& Wittorski, 2013) and management perspectives - as a socialisation of individuals in their professional environment (Jacobs \& Bosanac, 2006; Roquet \& 2014). (a) (b); Broussal, Caire, Techene, Castel-Lacanal \& De Boissezon, 2018), which ensures personal and professional development under the continuous competitiveness (Wittorski, 2009; 2012; Demazière, Roquet \& Wittorski, 2012). Le Boterf, 2016) in choosing among a wide variety of professionalisation ways that are considered as opportunities for professionalisation (Wittorski, 2007, 2008).

G. Le Boterf (2016) identified seven criteria to validate a person's professionalism, as such a person: 1) takes appropriate initiatives in complex, evolving, and unprecedented situations; 2) keeps track of the development of profession at the current level; 3) anticipates and takes into account important aspects of a problematic situation or even details of a minor customer request or need; 4) runs relevant professional practice and mobilises appropriate work resources; 5) cooperates effectively and seeks necessary external assistance; 6) learns from experience so that to transfer it to other practical contexts or to pass it on to other persons; 7) performs in accordance with ethical requirements.

The process of professionalisation implies the difference between traditional occupational training in university and the acquisition of skills in other ways (Roquet, 2014 (a, b)) based on different logic. For example, professionalisation ways might base on action, reflection, organisational culture, integration, etc. (Wittorski, 2012). So, if a public health specialist seeks to become a professional, he or she must consider the ways, methods, and opportunities for professionalisation, even though there are still gaps in his or her academic preparation for professional practice. One of these opportunities is learning in practical situations of professional activities (Henrard, 2019). However, this is highly difficult with no assistance of a mentor or a tutor, experienced colleagues or a community of practitioners who would open up learning opportunities in the workplace, in a specific professional situation. All the more so as all existing official documents and regulations in public health emphasise specific tasks for a specialist in that field, but they do not mention any personal status, professional identity, or opportunities for professionalisation (Cianciara, Sugay, Rutyna, Urban, Piotrowicz, Gajewska, Lewtak \& Gotlib, 2018, p. 140). Whereas everyone is well aware that “...public health services are to be professional to ensure global public health protection" (Burkle, 2014, p. 8). Therefore, we have to emphasise the relevance of the issue 
of professionalisation again and again. Perhaps this is why some countries, such as Canada, are founding professional development groups for public health specialists - communities of practitioners (Richard, Chiocchio, Essiembre, Tremblay, Lamy, Champagne \& Beaudet, 2014), with corresponding training programmes (Tremblay, Brousselle, Richard \& Beaudet, 2013).

In investigating the opportunities for professionalisation and professional development processes of players in learning situations of professional practice, R. Wittorski (2007) proposes to define professionalisation at three different levels:

- $\quad$ professionalisation of activities, by considering a social planning of activities as a whole;

- $\quad$ professionalisation of individuals (players). Becoming a professional happens with a view to construct and/or obtain, develop the knowledge, skills, competencies, and professional identity necessary for professional activities;

- $\quad$ professionalisation of organisations (structures), by emphasising the formalisation of the organisation's (or any other structure's) system of expertise.

In this study, we base on the above proposed concept of professionalisation of individuals (players) in the field of public health care so that to focus on specialists' competencies, personal status, prestige, construction of professional identity, and search for professionalisation opportunities.

R. Wittorski (2012) suggests discussing two aspects of the relevance of professionalisation: practical activities, that take place during internships, practical training, and professional practice, and reflection that emerges from theoretical training. Reflective practice is a purposeful intellectual activity in which individuals examine a situation or a problem on the basis of previous experience and seek to form new understanding, new knowledge that will ultimately affect their actions (Tremblay, Richard, Brousselle \& Beaudet, 2014, p. 2). Linking the two aspects of the relevance of professionalisation does not mean an analysis of only one of the aspects, splitting or elimination of the second one. It is necessary to apply the principles of intelligibility and comprehensibility to professional practical activities. It is hoped that the both aspects of professionalisation (practical activities and reflection) can be linked by helping a person to understand the professional practical activities, to obtain new competencies, to construct professional identity though the ways of professionalisation. Linking of them might enable to restore general social representations.

Along with the definition of factors for the relevance of professionalisation, R. Wittorski (2007) presents a tool (possible ways, i.e., opportunities of 
professionalisation) to analyse dynamics of the professionalisation supply and professional development of players. This tool allows examining the variety of forms and possible ways of professional activity arrangements that change the quantity and quality of tasks and actions in individuals' professional practice. Accordingly, they obtain new competencies and/or new knowledge, construct/reconstruct their professional behaviour and professional identity. R. Witorski's theoretical insights laid the groundwork for the following empirical study.

\section{Methodology and Process of the Research}

This empirical study was conducted in several phases, by using a qualitative research strategy.

First phase. At this phase of study, there were individual in-depth interviews conducted with public health professionals working in public health offices of different cities and towns (Klaipeda, Kaunas, Vilnius, Šiauliai and Panevėžys), with experience in providing health care services to persons with disabilities $(n=19)$. The interviews were aimed to identify possible professionalisation ways or opportunities for public health professionals providing services to people of all ages with disabilities under the continuous competitiveness. The specialists were interviewed in October-November of 2020. Study participants were selected though the targeted criterion-based sampling. It enables researchers to select sample units based on a specific established criterion (s). Only those public health professionals who provide services to persons with disabilities were invited to participate. These study participants were expected to define possible ways or opportunities for the professionalisation of public health professionals providing services to people with disabilities in the context of ongoing competitiveness. Individual interviews helped the researchers to collect a wealth of useful information, to communicate flexibly with people, to learn important details that generate new insights, since visual contact allows observing both cognitive and emotional aspects of responses. Besides, the researchers were able to clarify their questions and, thus, to increase the likelihood of gaining useful information and making in-depth examination of the problem. The interview method was not aimed at mutual communication or sharing of experiences - instead, each research participant was encouraged to share their personal experiences and feelings.

During the individual interview, the questionnaire was gradually elaborated to details on the basis of theoretical insights and practical experience. The data were collected by asking all participants the same initial question "What are the possible ways and opportunities for professionalisation of public health professionals who provide services to people with disabilities?" It was followed 
by clarifying interview questions to find out how the respondents describe the ways and opportunities of professionalisation. The interviews were recorded. In addition, the peculiarities of the informants' language, behaviour, and expression of emotions were recorded during the interviews. Interview duration was 58 minutes to 1 hour 15 minutes. After the session, remarks on the interviews were made, audio records were transcribed, and quotations from the informants' speeches were written down verbatim.

All participants were women ranging in age from 36 to 62 years. The participants' experience was 6 to 27 years.

Second phase. The obtained research data were examined using qualitative inductive and deductive content data analyses. The qualitative inductive content analysis consisted of open coding, creation and abstraction of categories (general description of the study based on the categories presented). Categories were created during the analysis process to describe the phenomenon of the professionalisation process under study, to increase understanding thereof, and to generate knowledge. The creation of categories and subcategories is the essence of the inductive content analysis; a text is interpreted on the basis of the research questions raised. The questions are answered through the developed categories and subcategories (Mayring, 2014).

The inductive content analysis was conducted in stages, which were followed in the processing of the research data obtained: 1 ) repeated reading of a text; 2) identification of key categories based on keywords; 3) breaking down of categories into subcategories; 4) interpretation of categories and subcategories and substantiation with evidence extracted from the text.

The data obtained during the interviews were processed using the qualitative deductive content analysis, since the researchers sought to replicate available data in a new context, to try categories, concepts, models, or hypotheses. The purpose of the deductive content analysis is conceptual validation or extension of the theory (Mayring, 2014).

Data for analysis were obtained through interviews with open-ended targeted questions which were developed according to pre-defined categories. During this analysis, there was a category matrix created based on R. Wittorski's (2007; 2008; 2014) ideas for the ways and opportunities of professionalisation.

Research ethics. In the study, the general ethical principles were followed:

- The principle of voluntariness. All participants were involved in the study voluntarily, of their free will. The subjects were informed about the purpose, the course, the planned duration of the study, their rights (to interrupt the interview at any time; not to answer unwanted questions; to control the amount of information they wanted to share). An oral consent of the subjects to participate in the study was obtained; 
- The principle of providing information on ethical issues. The study participants were explained how their anonymity and confidentiality would be ensured, they were informed on when and how they would find out the results of the study, contact details of the researcher were provided;

- The principle of confidentiality. This issue was discussed at the beginning of the study. It was explained to participants exactly what the confidentiality limits might be in the context of a particular study. Participants in the research were assured that the information obtained during the study would only be applied for the purposes of the study and might only be used by the researcher. The confidentiality of information in analysing and publishing the research material was assured;

- The principle of anonymity of subjects. To ensure that this principle was really applied, information about the subjects was presented in a way not to reveal their identities. The participants' statements were transcribed and presented as a general text of the interview, so it was not possible to decipher the participants' identities.

None of the above principles of research ethics were violated during the study, neither any misunderstandings arose. During every meeting, a communication-friendly atmosphere was created, an opinion of each participant was heard, and respect was ensured.

\section{Results of the Research: Possible Ways of Professionalisation of Public Health Professionals Providing Services to Persons of Different Ages with Disabilities}

The main question of the interview is: What are the possible professionalisation ways (opportunities) for public health professionals providing services to persons with disabilities?

With reference to R. Wittorski (2007; 2008; 2012), in order to make the main research question more detailed, the study participants were asked to answer the following questions: What does work-based learning mean to you? How do you understand reflection and your occupation in providing services to people with disabilities? How are the construction and development of new competencies taking place in your practice? What changes in occupation, behaviours, and identity lie ahead? Who helps you to improve yourself in the organisation and how? Have you managed to integrate your existing knowledge into your personal knowledge system, given the situations in your professional activity? Has that knowledge been recognised and have you shared it with others? 
SOCIETY. INTEGRATION. EDUCATION

Proceedings of the International Scientific Conference. Volume IV, May $28^{\text {th }}-29^{\text {th }}$, 2021. 274-293

The inductive content analysis of research data has allowed identifying the following categories and subcategories of possible ways or opportunities for professionalisation of public health professionals:

Table 1 Categories and Subcategories of Professionalisation Ways and Opportunities of Public Health Professionals Providing Services to Persons with Disabilities

\begin{tabular}{|l|l|}
\hline \multicolumn{1}{|c|}{ Categories } & \multicolumn{1}{|c|}{ Subcategories } \\
\hline 1. Work-based learning (or, & 1.1. Obtaining new competencies \\
learning in the workplace) & 1.2. Mastering new situations in professional activities \\
& 1.3. Construction and development of professional \\
behaviour, professional identity
\end{tabular}

So, six statement categories as well as supplementing and clarifying subcategories were obtained. The assigned subcategories and respective illustrating fragments from the interviews are provided in the tables below. 
Anužiene et al., 2021. Discourse on Professionalisation in the Practice of Public Health Professionals Providing Services to Persons with Disabilities

Table 2 Fragments and Statements Illustrating the Subcategories under the Category (1) “Work-based Learning”

\begin{tabular}{|c|c|}
\hline Subcategory & Fragments illustrating the interview \\
\hline $\begin{array}{l}\text { 1.1. Obtaining new } \\
\text { competencies }\end{array}$ & $\begin{array}{l}<\ldots \text { can't say that we didn't know anything about disability back in the } \\
\text { years of university, ... we knew but we didn't know much about how to } \\
\text { carry out preventive activities for people of different ages with } \\
\text { disabilities >; <no one, no teacher can teach competencies, we obtain } \\
\text { them, we get them here, in the workplace }>\text {; <...there is a specific } \\
\text { description of competencies provided for in the job instructions, you } \\
\text { need not just to know them, but to obtain them, too; you might sit in } \\
\text { the classroom and read them, know them, but when you start acting, } \\
\text { things look different }>\text {; <...it was good for us that we had the } \\
\text { opportunity to watch in the workplace how senior colleagues } \\
\text { provided services to people of all ages with disabilities }>\text {; <...I was } \\
\text { personally aided and taught by my colleague who had been giving } \\
\text { classes for adults and children with disabilities for a long time, and I } \\
\text { should say that they were quite different in their methods>; <...I } \\
\text { conducted safety training for people with disabilities ... at first it was } \\
\text { not perfect; I saw that I was doing wrong, my peer watched me and } \\
\text { then told me what was wrong }>\text {; <...I kept watching others work for } \\
\text { years as I was very anxious that I would fail, I did not feel confident } \\
\text { and I really did not want to hurt the dignity of people with } \\
\text { disabilities>; <...those discussions after work were both much- } \\
\text { needed and intimidating, it is not fun when you are shown your } \\
\text { errors, but so it goes... you will not learn otherwise >; <... isn't it } \\
\text { possible to agree that sometimes errors could be more tolerated }>\end{array}$ \\
\hline $\begin{array}{l}\text { 1.2. Mastering new } \\
\text { situations in } \\
\text { professional } \\
\text { activities }\end{array}$ & $\begin{array}{l}<\ldots \text { it took a long time for me to start providing better services to } \\
\text { people with disabilities... many new situations arose, I did not know } \\
\text { how to work with children with disabilities }>\text {; <...because every time } \\
\text { a new group, new people come to you, and you feel like you can't } \\
\text { apply everything from the previous experience, you need to change } \\
\text { something again or you don't know something at all }>\text {; <... a new } \\
\text { practical situation stays new until you master it, but I like new } \\
\text { things }>\text {; <...when you face a new situation, at first, you feel anxious, } \\
\text { then you start thinking what it is about, what you can apply now, } \\
\text { what is needed and what is not, you also ask for advice, you inquire, } \\
\text { read something and all is going OK }>\text {; <...one way or another, a new } \\
\text { situation is good as we grow and improve ourselves through them }>\text {; } \\
<\ldots \text { my competencies are a puzzle made up of managing each new } \\
\text { situation, of course, not without the help of colleagues }>\end{array}$ \\
\hline
\end{tabular}




\begin{tabular}{|c|c|}
\hline $\begin{array}{l}\text { 1.3. Construction } \\
\text { and development } \\
\text { of professional } \\
\text { behaviour, } \\
\text { professional } \\
\text { identity }\end{array}$ & $\begin{array}{l}<\ldots \text { if you know what needs to be done, you do it the right way, then } \\
\text { the right professional behaviour develops; though, after graduation, I } \\
\text { really didn't know how to teach, to give classes }>\text {; <...but to know } \\
\text { what you do, how you do, you need to have knowledge, not just } \\
\text { experience>; <...during my internship in bachelor studies, I saw what } \\
\text { a good specialist should be, I have my own vision, I try to become } \\
\text { what I would like to be >; <...only after starting the practice, you find } \\
\text { what you really should be like because you are influenced by } \\
\text { colleagues, clients, managers...>; <...upon gaining experience, you } \\
\text { can see the difference between who you were and who you become }>\text {; } \\
<\ldots \text { many new situations which you must master change both your } \\
\text { behaviour and yourself }>\end{array}$ \\
\hline
\end{tabular}

The first way of professionalisation corresponds to the model of workbased learning: new situations in professional activities oblige a person to obtain new competencies. They can also be obtained through trials and errors: this is the logic of action. This usually happens in a well-known professional situation (e.g., during an internship or practical training). However, once a player on this way faces a new practical situation, he or she often unconsciously corrects his or her behaviour, constructs/reconstructs his or her professional identity. Each time a new situation arises, an individual will repeat or reinforce that behaviour and identity.

Table 3 Fragments and Statements Illustrating the Subcategories under the Category (2) "Reflection and Activities"

\begin{tabular}{|c|c|}
\hline Subcategory & Fragments illustrating the interview \\
\hline $\begin{array}{l}\text { 2.1. Changes } \\
\text { and adjustment } \\
\text { of theoretical } \\
\text { knowledge } \\
\text { transmission in } \\
\text { the classroom } \\
\text { and } \\
\text { competency } \\
\text { development } \\
\text { during the } \\
\text { practical } \\
\text { training or } \\
\text { internship }\end{array}$ & $\begin{array}{l}<\ldots \text {...uring my undergraduate years, I understood very well that the } \\
\text { knowledge gained in the classroom and the experience gained during } \\
\text { the internship had to match; but did it always match?>; <...while } \\
\text { studying and working, it is obviously difficult but valuable, because my } \\
\text { knowledge sometimes updates the previous knowledge of my colleagues, } \\
\text { I feel proud in such cases }>\text {; <...I always think in a practical situation, } \\
\text { what I know from my studies on the subject, then it is easier to act; but } \\
\text { sometimes I don't remember anything...>; <...in my opinion, practice } \\
\text { and specific activities are intended for your success, while studies and } \\
\text { theory - for your understanding. These two things can in no way be } \\
\text { separated >; <...but we should not forget that public offices still have } \\
\text { employees who do not have any special qualifications in public health, } \\
\text { even though they provide the same services >; <...they attend a lot of } \\
\text { various courses, workshops and their experience is powerful, it is, } \\
\text { nonetheless, a combination of knowledge and competencies }>\end{array}$ \\
\hline $\begin{array}{l}\text { 2.2. Changes } \\
\text { in professional } \\
\text { behaviour, }\end{array}$ & $\begin{array}{l}<\ldots I \text { finish my job and think about what I could do better next time to } \\
\text { feel more successful, more confident }>\text {; <...we have the tradition in our } \\
\text { office: we gather once a month and tell each other what we would like to }\end{array}$ \\
\hline
\end{tabular}


professional identity based on performance reflection

do differently, better than we did, what went rather wrong... >; <...if I
compared myself a few years ago to the current "me", I would hardly
recognise that timid, under-confident girl who didn't know how to go to
the health promotion session tomorrow and what to say to that group of
disabled children>; <... always ask myself if now I really understand
what it means to provide services to people with disabilities, and this
"pushes" me to go deeper and deeper into myself, into my work, this
changes me... I found more empathy and understanding of others in
myself $>$; <...reflection is more than just a process, it is also a
competency that helps me empathise with the state of a disabled
person>

do differently, better than we did, what went rather wrong... >; <...if I compared myself a few years ago to the current "me", I would hardly recognise that timid, under-confident girl who didn't know how to go to disabled children>; <...I always ask myself if now I really understand what it means to provide services to people with disabilities, and this "pushes" me to go deeper and deeper into myself, into my work, this changes me... I found more empathy and understanding of others in myself>; <...reflection is more than just a process, it is also a person>

The second way of professionalisation is related to the changes and adjustment of theoretical knowledge transmission in the classroom and competency development during the practical training or internship: this is the logic of reflection and action. When performing a new task, an individual consciously changes his or her behaviour on the basis of the reflection of action.

Table 4 Fragments and Statements Illustrating the Subcategories under the Category (3) "Reflection on Activities (formalisation of unexpressed competencies)"

\begin{tabular}{|c|c|}
\hline Subcategory & Fragments illustrating the interview \\
\hline $\begin{array}{l}\text { 3.1. Competency } \\
\text { generation } \\
\text { (construction) } \\
\text { during activities }\end{array}$ & $\begin{array}{l}<\ldots \text { you'll have no competencies until you start working yourself }>\text {; } \\
<\ldots \text { when you do, "taste" a job yourself, it looks completely different, } \\
\text { it either works out or doesn't }>\text {; <...you may know how to do a task, } \\
\text { but competencies come only when you start to do it }>\text {; <...of course, it } \\
\text { is not fun to start a new job without knowing how to do it, but there is } \\
\text { also another way - through errors and trials }>\end{array}$ \\
\hline $\begin{array}{l}\text { 3.2. Transformation } \\
\text { of competencies } \\
\text { into professional } \\
\text { knowledge }\end{array}$ & $\begin{array}{l}<\ldots \text { it is not so easy to put into words what you do }>\text {; <...as long as } \\
\text { you find no right words to explain your activity, you cannot say that } \\
\text { you are competent }>\text {; <...if I analyse my activity, if I can describe it in } \\
\text { words to another person, to myself, only then it means that I got it, I } \\
\text { mastered, learned it, I managed }>\text {; <...this is the way you accumulate } \\
\text { experience, practical knowledge and develop competencies }>\text {; <...by } \\
\text { reflecting, a future specialist obtains "invisible" knowledge and } \\
\text { skills, so he can choose the right strategies, make adequate decisions } \\
\text { not only in professional activities, but in various life situations, too }>\end{array}$ \\
\hline $\begin{array}{l}\text { 3.3. Validation and } \\
\text { recognition of } \\
\text { competencies }\end{array}$ & $\begin{array}{l}<\ldots \text {...naturally, not just you, but other persons as well must } \\
\text { acknowledge and validate your competence }>\text {; <...if colleagues say } \\
\text { that I am unsatisfactory in my job performance, I should listen to } \\
\text { them; on the other hand, it may not be just a matter of goodwill, } \\
\text { given today's competitive environment }>\text {; <...there is an evaluation of } \\
\text { performance taking place; when my performance is acknowledged as } \\
\text { appropriate, my competencies are acknowledged, too }>\text {; <...service } \\
\text { users judge my performance, I kept comparing the results of my } \\
\text { performance evaluation, I see how they changed over the years. And } \\
\text { that change went in a positive direction }>\end{array}$ \\
\hline
\end{tabular}


The third way of professionalisation is the formalisation of unexpressed competencies, whereby competencies are generated (constructed) during an action and then turn into practical knowledge. Therefore, competencies need to be expressed in words, and the latter are to be transformed into communicable and professionally validated knowledge. Such knowledge, thus, is well understood and can be passed on to other people: this is the logic of reflection on action. An individual analyses an action retrospectively in order to better understand it. By perceiving his or her actions, in particular, by analysing his or her practice, he or she accumulates knowledge of actions.

Table 5 Fragments and Statements Illustrating the Subcategories under the Category (4) "Reflection for Activities"

\begin{tabular}{|c|c|}
\hline Subcategory & Fragments illustrating the interview \\
\hline $\begin{array}{l}\text { 4.1. Anticipation } \\
\text { of future } \\
\text { performance } \\
\text { changes in } \\
\text { professional } \\
\text { practice }\end{array}$ & $\begin{array}{l}<\ldots \text {...in order to anticipate changes in performance, it is important to } \\
\text { actualise the connection between theory and practice, the interaction } \\
\text { of personal and professional experience in professional activities, } \\
\text { otherwise it will fail>; <...by reflecting, we get to know ourselves, we } \\
\text { look at the same problem from different perspectives, reflect not only } \\
\text { on positive but also on negative experiences, and perceive our } \\
\text { weaknesses and strengths; all of which allow us to anticipate future } \\
\text { changes in our performance>; <...we must all be reflective } \\
\text { practitioners, constantly develop our competencies needed for } \\
\text { successful future professional activities }>\end{array}$ \\
\hline $\begin{array}{l}\text { 4.2. Anticipation } \\
\text { of desirable } \\
\text { effective } \\
\text { performance } \\
\text { criteria }\end{array}$ & $\begin{array}{l}<\ldots \text {...not all effective performance criteria are provided for in job } \\
\text { descriptions, daily tasks rather often show how effective our } \\
\text { performance might be }>\text {; <...of course, an actual professional activity } \\
\text { may differ from the one provided for in a job description, and the } \\
\text { criteria are often specified by the manager of the unit }>\text {; <...it is a } \\
\text { good thing if a whole team agrees on the criteria for effective } \\
\text { performance, but sometimes, if they are not formally documented, } \\
\text { misunderstanding may arise }>\text {; <... what may work for me may not } \\
\text { seem effective to my manager, consensus is needed, therefore, } \\
\text { common criteria are necessary }>\end{array}$ \\
\hline $\begin{array}{l}\text { 4.3. Anticipation } \\
\text { of desirable } \\
\text { professional } \\
\text { behaviour, } \\
\text { professional } \\
\text { identity }\end{array}$ & $\begin{array}{l}<\ldots \text { when we know the performance criteria, we can anticipate the } \\
\text { desired behaviour }>\text {; <...and the behaviour can show whether a } \\
\text { person is our kind of guy, a professional of our field or not }>;<\ldots \text { after } \\
\text { all, it happens that a person looks like working, doing his best, but } \\
\text { our occupation does not fit him, he is not our kind of guy }>\text {; <...not } \\
\text { everyone fits to work with people with disabilities, not everyone can } \\
\text { work with children, on the contrary, others do not like working with } \\
\text { adults }>\text {; <...therefore, given the performance criteria, such as those } \\
\text { defining the activities of a public health professional in the provision } \\
\text { of services to people of all ages with disabilities, you should definitely } \\
\text { need to try again answering the question of who I am in a particular } \\
\text { professional situation }>\end{array}$ \\
\hline
\end{tabular}


The fourth way of professionalisation is known as the logic of reflection for action. These are situations where professionals (specialists) of competency development teams or problem-solving teams define a new practice in advance, taking into account the effective performance criteria that they will introduce (or would like to introduce) in their professional activities. This is a phase of prereflection to anticipate changes in future actions.

Table 6 Fragments and Statements Illustrating the Subcategories under the Category (5) “Organisational Culture and Activities”

\begin{tabular}{|c|c|}
\hline Subcategory & Fragments illustrating the interview \\
\hline $\begin{array}{l}\text { 5.1. Mentor, } \\
\text { adviser, peer, } \\
\text { or other } \\
\text { knowledge } \\
\text { transmission }\end{array}$ & $\begin{array}{l}<\ldots \text { with the help of a peer, a mentor, one learns to identify their attitudes, } \\
\text { positions, and values, to integrate new understanding and to develop } \\
\text { generalisations that allow making positive changes in their learning or } \\
\text { future professional situations }>\text {; <...a peer's or a mentor's objective } \\
\text { cooperation, giving feedback on learning effectiveness and outcomes help } \\
\text { a future professional to monitor their learning and understand the } \\
\text { knowledge system >; <...rightly so, 'Show me and I will understand.' A } \\
\text { mentor's work is invaluable>; <...it would be great for an organisation's } \\
\text { cultural policy to have a clear objective to incorporate mentorship }>\end{array}$ \\
\hline $\begin{array}{l}\text { 5.2. General } \\
\text { construction of } \\
\text { a new } \\
\text { professional } \\
\text { practice }\end{array}$ & $\begin{array}{l}<\ldots \text { when employees are proud of their work, when their job is interesting } \\
\text { and important to them, when they are loyal to the organisation, when } \\
\text { employee mistakes are tolerated, when conflicts between employees are } \\
\text { resolved through negotiations - yes, then it is possible to construct new } \\
\text { practices together; in brief, it depends on many things> }\end{array}$ \\
\hline $\begin{array}{l}\text { 5.3. Changes in } \\
\text { attitudes } \\
\text { towards the } \\
\text { situation in } \\
\text { professional } \\
\text { activities when } \\
\text { providing } \\
\text { services to } \\
\text { persons with } \\
\text { disabilities }\end{array}$ & $\begin{array}{l}<\ldots \text { only a mentor or a peer being in good faith can clearly show how to } \\
\text { do the job, who owns the fruits of work, the relations with supervisors and } \\
\text { other institutions }>\text {; <... a peer, a mentor, an adviser help to understand } \\
\text { what people's communication norms, control, priority of spiritual or } \\
\text { material values should be, how and in what language to express ideas } \\
\text { and relations, what symbols reflect the organisational culture }>\text {; } \\
<\ldots \text {..people's relations with the state, legal and political methods of } \\
\text { maintaining order }>\text {; <...organisational culture can help a professional } \\
\text { not only to understand but also to change their attitude towards our } \\
\text { relationship with the state, legal and political policing requirements }>\text {; } \\
<\ldots \text { in the absence of clear beliefs or values, one may not understand how } \\
\text { to make change in the development of one's activities }>\text {; <...in order to } \\
\text { change our approach to a practical situation, we need to know the core } \\
\text { values of the organisation that are recognised }>\end{array}$ \\
\hline
\end{tabular}

The fifth way of professionalisation implicates situations in professional activities, when a third party (a peer, a tutor, a mentor, an adviser, etc.) conducts the transmission of knowledge and general construction of new practices, modifies an approach to a professional situation. This is the logic of cultural expression of an organisation in terms of action. In this case, the third party 
(a peer, a tutor, a mentor, an adviser, etc.) supports the activities carried out, contributes by transmitting the existing knowledge, and, thus, enables a future professional to look at the activities differently.

Table 7 Fragments and Statements Illustrating the Subcategories under the Category (6) "Integration/assimilation of Knowledge"

\begin{tabular}{|c|c|}
\hline Subcategory & Fragments illustrating the interview \\
\hline $\begin{array}{l}\text { 6.1. Integration of } \\
\text { theoretical knowledge } \\
\text { into one’s own personal } \\
\text { knowledge and skills } \\
\text { system }\end{array}$ & $\begin{array}{l}<\ldots \text { there is no practice without theory, and vice versa }>\text {; }<\ldots \text { an } \\
\text { action is often based on a theory; it is not so much important } \\
\text { whether a person knows that such a theory exists - more } \\
\text { important that this theory becomes part of your occupation, } \\
\text { your personal experience }>\text {; <...I believe that theoretical } \\
\text { knowledge is the basis for successful practice }>\end{array}$ \\
\hline $\begin{array}{l}\text { 6.2. Transformation of } \\
\text { theoretical knowledge, } \\
\text { taking into account } \\
\text { specific situations in } \\
\text { professional activities, } \\
\text { when providing services } \\
\text { to persons with } \\
\text { disabilities }\end{array}$ & $\begin{array}{l}<\ldots \text { in many real-life situations in professional activities, I was } \\
\text { able to effectively apply the knowledge obtained in studies }>\text {; } \\
<\ldots \text { everyone individually seeks to understand theories, to } \\
\text { identify their elements, and to apply them in new practical } \\
\text { situations by reflecting on, substantiating, and interpreting } \\
\text { their actions >; <...while working, I finally realised how theory } \\
\text { could be linked to practice>; <...for theory to turn into } \\
\text { practical skills, competencies, you need experience, some } \\
\text { particular professional aspiration }>\end{array}$ \\
\hline $\begin{array}{l}\text { 6.3. Recognition of } \\
\text { newly created knowledge }\end{array}$ & $\begin{array}{l}<\ldots \text { knowledge gained from experience or practical activity is } \\
\text { not always correct }>\text {; <...it would be great if that knowledge } \\
\text { was verified by scholars in our field }>\text {; <...after all, reading, } \\
\text { keeping track of the latest literature allows understanding } \\
\text { whether the knowledge created in practice is sound and } \\
\text { correct }>\text {; <...new knowledge is created in our practical } \\
\text { activities not so often }>\end{array}$ \\
\hline
\end{tabular}

Theoretical knowledge, obtained in learning by the sixth way of professionalisation, is integrated by individuals into their personal knowledge and skills system. The system, correspondingly, will be the framework for different skills that acquire forms of different competencies, as circumstances require. Learning conveys theoretical knowledge that individuals will need to transform as suited the situations in professional activities. This is the logic of integration/assimilation. In this case, a person uses documents, information resources, reading, and exercises to develop his or her skills. Therefore, it is a pathway oriented towards theory rather than a person's practical activities. 


\section{Conclusions}

The global economy brings not just threats and risks, but opportunities for professionalisation, as well, by gaining a competitive advantage in different ways.

The study shows that the professionalisation of public health specialists shifts to professional activities after their graduation and that professionalisation ways (or, in other words, opportunities) may vary. The study has established that that the ways of professionalisation (1.Work-based learning; 2.Reflection and activities; 3.Reflection on activities (formalisation of unexpressed competencies); 4.Reflection for activities; 5.Organisational culture and activities; 6.Integration/assimilation of knowledge) enable a person to develop existing competencies, to construct a professional identity through the integration of both aspects of relevance of professionalisation ways: practical activities and reflection. One of them is Work-based learning. In obtaining new competencies through professional activities, the study participants emphasised: the need for preventive activities, health care services for people of all ages with disabilities, tolerance of professional errors, trust, monitoring by experienced peers, performance analysis, peer support, independent learning, and acquisition of competencies in activities. In mastering new situations in professional activity, the study participants indicated the following aspects: new situations emerging in professional activity, time needed for mastering them, peer support, construction of competencies, development thereof. In constructing and developing professional behaviour and professional identity, the following was important for the research participants: understanding of activities, need for theoretical knowledge, impact of new situations and environment on behaviour, identity, and changes in the latter.

The second pathway to professionalisation, as the study shows, is Reflection and professional activity. The coherence of the obtained theoretical knowledge and experience, as well as its benefits, support in application of reflection during professional activities were important for the study participants. The participants of the research believe that, based on the reflection of activities, changes in professional behaviour and professional identity are possible.

The third possible way of professionalisation of public health professionals is Reflection on activities (formalisation of unexpressed competencies). The research participants, speaking on this issue, emphasised the construction of competencies in and through activities, the expression of existing competencies in words, communication, accumulation of knowledge gained through experience, performance evaluation, recognition, linking with existing competencies, and validation of knowledge gained through activities. 
The fourth possible pathway to professionalisation is Reflection for activities. The following main statements were accentuated in the speeches of the research participants: links between reflection and changes in activity, selfcognition and cognition of one's activities through reflection, common responsibility for effective performance criteria, impact of activities, of anticipating criteria for desirable behaviours on the identity of public health professionals providing services to persons with disabilities.

The fifth possible way of professionalisation of public health professionals is Organisational culture and activities. The research found that the transmission of knowledge in a professional situation, while providing services to people of different ages with disabilities, might take place with assistance of peers, a mentor, an adviser, or other persons. The participants of the research indicated the following factors for ensuring the construction of general activities: pride, interest in their work, loyalty to the organisation, conflict resolution, etc. A change in the attitude towards a professional situation in the provision of services to persons with disabilities depends on the economic, social, and political cultural context of the organisation favourable to the specialist.

The last, sixth possible way of professionalisation of public health professionals is Integration/assimilation of knowledge. The ability to integrate theoretical knowledge into practice and vice versa, as one of the goals of professional development, seemed to be of high importance to the study participants. Therefore, the following factors were emphasised during the research: perception of the importance of theory in practical activities; giving a sense to knowledge in practical activities. The transformation of theoretical knowledge takes into account specific practical situations in the provision of services to persons with disabilities. It, is, therefore, necessary to individualise the coherence of theory and practice with due regard to the following elements: the perspective of experience, knowledge, aspirations and activity. It is however acknowledged that knowledge created in experience is not always scientifically correct, therefore, it must be validated and recognised.

The study has revealed that there are two concepts merging in the process of professionalisation: learning (with the need for new knowledge and competencies to be obtained) and the acquisition of competencies, which means becoming a professional. The results of the study show that the dimensions of professionalisation of individuals (professionalism and professionism) are manifested by choosing one or a combining several different ways thereof, deemed as opportunities. The choice of opportunities (ways) for professionalisation is necessary when a public health professional, providing services to persons of different ages with disabilities, pursues new competencies, new knowledge required for the performance of professional 
activities (professionalism). The same applies to the needs of constructing professional identity, social status, consolidating prestige (professionism). Both meanings of the professionalisation process, i.e., professionalism and professionism, should be particularly relevant for both those responsible for training future professionals and an organisation itself, since professionalisation is a continuous process of becoming professionals, given the available content of the profession and future changes in professional activities. After all, becoming a professional is the only way to secure a long-term competitive advantage for yourself and your organisation.

\section{References}

Baranauskienė, I. (2020). Teisès ị sveikatos priežiūra paradoksas. Monografija [The Paradox of the Right to Health Care. Monograph]. Klaipèda: Klaipeda University Press.

Bourdoncle, R. (2000). Professionnalisation, formes et dispositifs. Recherche et formation, $\mathrm{n}^{\circ}$ 35, p. 117-132. Sous la direction de Altet, M. \& Bourdoncle, R. Retrieved from https://doi.org/10.3406/refor.2000.1674

Bourdieu, P. \& Wacquant, L. (1992). Réponses. Pour une anthropologie réflexive. Paris: Éditions du Seuil.

Bresnen, M. (2013). Advancing a 'new professionalism': professionalisation, practice and institutionalization. Building Research \& Information, 41(6), 735-741. Retrieved from https://ezproxy.biblioteka.ku.lt:4400/10.1080/09613218.2013.843269

Broussal, D., Caire, J.-M., Techene, S., Castel-Lacanal, E., \& De Boissezon, X. (2018). S'étonner pour se professionnaliser: une expérience d'immersion sur le terrain en première année de formation d'ergothérapeutes. Revue Education et Socialisation, 49, 153-167. Retrieved from https://ezproxy.biblioteka.ku.lt:4400/10.4000/edso.3155

Burkle, F. M. (2014). Conversations in disaster medicine and public health: the profession. Disaster Medicine and Public Health Preparedness, 8(1), 5-11. Retrieved from https://ezproxy.biblioteka.ku.lt:4400/10.1017/dmp.2014.11

Cianciara, D., Sugay, L., Rutyna, A., Urban, E., Piotrowicz, M., Gajewska, M., Lewtak, K., \& Gotlib, J. (2018). Looking for professional identity of public health workers in Poland. Polish Journal of Public Health, 128(4), 139-143. Retrieved from https://ezproxy.biblioteka.ku.lt:4400/10.2478/pjph-2018-0027

Demazière, D., Roquet, R. \& Wittorski, R. (2012). La professionnalisation mise en objet. Paris: L'Harmattan, collection Action et Savoir. Retrieved from https://hal.archivesouvertes.fr/hal-01522845

Glouberman, S. \& Mintzberg, H. (2002). Gérer les soins de santé et le traitement de la maladie. Gestion, vol. 27(3), 12-22. doi:10.3917/riges.273.0012

Graber, M. \& Haberey-Knuessi, V. (2017). Le bachelor en soins infirmiers: entre professionnalisation et professionnalité en Suisse et en Belgique. Recherche en soins infirmiers, 128(1), 66-78. doi:10.3917/rsi.128.0066.

Guillaumin, C \& Wittorski, R. (2014). Situation professionnelle et alternance: un art de faire complexe. Education permanente (426), Hors- série, p. 54-64. Retrieved from http://www.educationpermanente.fr/public/articles/articles.php?id_revue=1726\&id_arti cle=2287\#resume2287 
Henrard, J. (2019). Quelques enseignements tirés du dernier congrès européen de santé publique. Santé Publique, vol. 31(6), 749-750. doi:10.3917/spub.196.0749.

Jacobs, M. \& Bosanac, S.E. (2006). The Professionalisation of Work. Whitby, ON: de Sitter Publications.

Le Boterf, G. (2016). Professionnaliser: Construire des parcours personnalisés de professionnalisation. Paris: Eyrolles.

Levesque, M., \& Gervais, C. (2000). L’insertion professionnelle: une étape réussir dans le processus de professionnalisation de l'enseignement (Professional Induction: A Stage To Succeed in during the Process of Professionalising Teaching). Education Canada, [s. l.], v. 40, n. 1, p. 12-15, 2000. Retrieved from http://ezproxy.biblioteka.ku.lt:2055/ login.aspx?direct=true\&db=eric\&AN=EJ603981\&lang=fr\&site=ehost-live

Mayring, Ph. (2014). Qualitative content analysis: theoretical foundation, basic procedures and software solution. Monographie. Klagenfurt. Retrieved from http://nbnresolving.de/urn:nbn:de:0168-ssoar-395173

Order of the Minister of Health of the Republic of Lithuania. (2018). No. V-342 of 26 March 2018 "On the Amendment of the Order of the Minister of Health of the Republic of Lithuania V-918 of 15 November 2007 'On the Approval of the List of Mandatory Positions in the Municipal Public Health Bureau and the Qualification Requirements for Them'." Vilnius: Seimas of the Republic of Lithuania. Retrieved from https://eseimas.lrs.lt/portal/legalAct/lt/TAD/d5f56cd1318611e8ab62b6c0fc2adb3f

Poulin, M. (2016). Accompagner un moment de transition professionnelle par un dispositif de formation-action réflexif mené auprès de conseillers en orientation et en accompagnement professionnels. Revue Phronesis, [s. l.], v. 4, n. 4, p. 27-45, 2016. DOI 10.7202/1036711ar. Retrieved from http://ezproxy.biblioteka.ku.lt:2055/ login.aspx?direct=true\&db=asn\&AN=115006683\&lang=fr\&site=ehost-live

Richard, L., Chiocchio, F., Essiembre, H., Tremblay, M.-C., Lamy, G., Champagne, F. \& Beaudet, N. (2014). Communities of practice as a professional and organisational development strategy in local public health organisations in Quebec, Canada: An evaluation model. Healthcare Policy, 9(3), 26-39. Retrieved from: https://www.ncbi.nlm.nih.gov/pmc/articles/PMC3999567/

Roquet, P. (2014 (a)). Rhythmes dans les activités formatives et professionnelles: une compréhension des temporalités dans la construction des processus de professionnalisation. Revue Phronesis, Volume 3, No 4, p. 56-62. Retrieved from https://doi.org/10.7202/1028786ar

Roquet, P. (2014 (b)). L'expérience comme processus mobilisateur de la professionnalisation. Education permanente (198), 51-58. Retrieved from http://www.education-permanente. fr/public/articles/articles.php?id_revue=1727\&id_article=2304\#resume2304

Roquet, P \& Wittorski, R. (2013). Professionnalisation et déprofessionnalisation: des liens consubstantiels, Recherche et Formation, (72), p. 71-88. Retrieved from https://doi.org/10.4000/rechercheformation.2038

Roquet, P. (2013). Temporalités et temps vécu. In Roquet, P., Gonzalves, M-J., Roger, L., Viana-Caetano, A-P. Temps, temporalités et complexité dans les activités éducatives et formatives. Paris: L'Harmattan, collection Ingenium, p.12-20. Retrieved from http://rhuthmos.eu/spip.php?article967

Roquet, P. (2012). La mise en objet de la professionnalisation: une réflexion articulée autour de trois niveaux d'activités formatives et professionnelles. In Demaziere, D., Roquet P., Wittorski, R. (eds.), La professionnalisation mise en objet. Paris: L’Harmattan, 
collection Savoir et Action, p. 17-29. Retrieved from https://hal.archivesouvertes.fr/hal-01522845

Tremblay, M.-C., Brousselle, A., Richard, L. \& Beaudet, N. (2013). Defining, illustrating and reflecting on logic analysis with an example from a professional development program. Evaluation and Program Planning, 40(1), 64-73. DOI: http://dx.doi.org/10.1016/j. evalprogplan.2013.05.004

Tremblay, M.-C., Richard, L., Brousselle, A. \& Beaudet, N. (2014). Learning reflexively from a health promotion professional development program in Canada. Health Promotion International, 29(3), 538-548. DOI: http://dx.doi.org/10.1093/heapro/dat062

Wittorski, R. (2007). Professionnalisation et développement professionnel. Paris: L’Harmattan. DOI: https://doi.org/10.4000/questionsvives.632

Wittorski, R. (2008). La professionnalisation. Savoirs, 17(2), 9-36. DOI : https://doi.org/ 10.3917/savo.017.0009

Wittorski, R. (2009). A propos de a professionnalisation. Encyclopédie de l'éducation et de la formation. PUF, pp.781-793. Retrieved from: https://hal.archives-ouvertes.fr/hal00601567/file/encyclopA_die-RW.pdf

Wittorski, R. (2012). La professionnalisation: enjeux, significations et voies. In B. Raveleau \& F. Ben-Hassel (éd.) Professionnalisation de la fonction RH, nouveaux enjeux et nouvelles approches (p. 15-37). Québec: PUL (Presses de l’Université Laval). Retrieved from https://excerpts.numilog.com/books/9782763796444.pdf

Wittorski, R. (2014). Professionnaliser par la formation. Sens et difficultés. Phronesis. Retrieved from http://www.revue-phronesis.com/ professionnaliser-formation 